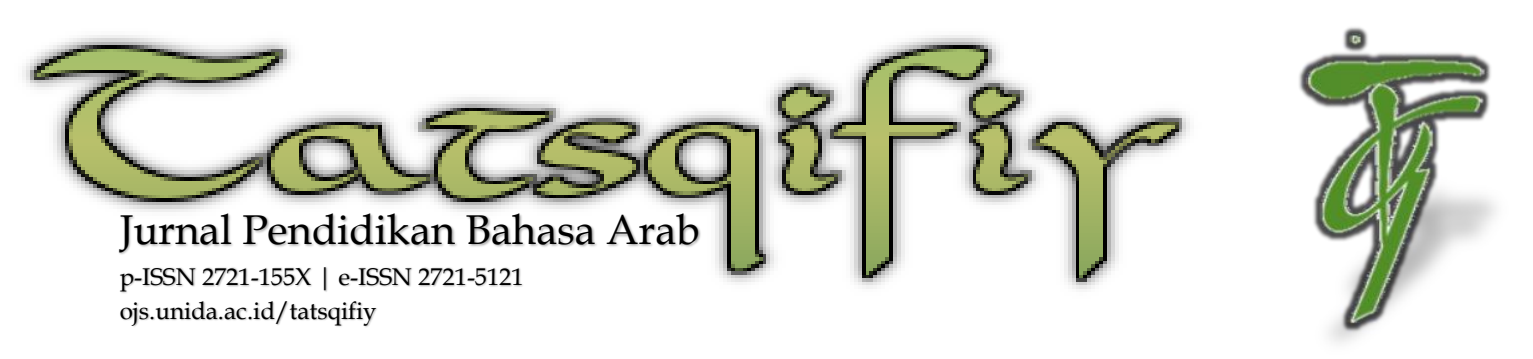

\title{
Flashcard: Belajar Mufrodat Bahasa Arab Semakin Menantang
}

\author{
Fachri Helmanto \\ Universitas Djuanda
}

Volume 1 Nomor 2
Juli 2020: 141-151
DOI: $10.30997 /$ tjpba.v1i2.3091

Article History

Submission: 19-07-2020

Revised: 28-07-2020

Accepted: 30-07-2020

Published: 31-07-2020

Kata Kunci:

mufrodat, studi literatur, flashcard bahasa asing

Keywords:

foreign language flashcard, literature study, Vocabulary,

Korespondensi:

Fachri Helmanto

fachri.helmanto@unida.ac.id

\begin{abstract}
Abstrak: Flashcard mendorong peserta didik untuk meningkatkan penguasaan kosakata (mufrodat). Namun, pembelajaran menggunakan Flashcard sejauh ini masih dinilai membosankan. Penelitian ini bertujuan untuk mengungkap sejauh mana Flashcard diproduksi dan digunakan dalam proses pembelajaran bahasa asing di Indonesia (bahasa Inggris dan bahasa Arab). Metode yang digunakan dalam penelitian ini adalah studi literatur dengan mengumpulkan sejumlah dokumen artikel 10 tahun terakhir atas penelitian Flashcard berbahasa Inggris dan berbahasa Arab. Selain artikel, kepustakaan berupa buku dan Flashcard multibahasa juga turut menjadi data penelitian sekaligus dipergunakan sebagai alat validasi dengan menggunakan teknik triangulasi sumber data. Hasil penelitian ini mengungkap produksi Flashcard berbahasa Arab belum banyak menggunakan ragam tema sebagai-mana Flashcard bahasa Inggris. Selain itu, pemanfaatan Flashcard dalam ragam metode pembelajaran dapat membuat peserta didik merasakan pembelajaran yang menantang. Oleh karena itu, penelitian selanjutnya direkomendasikan untuk mengembangkan produk Flashcard dengan berdasarkan tema.

\begin{tabular}{l}
\hline Flashcard: Learning Arabic Mufrodat Increasingly \\
Challenging \\
Abstract: Flashcards encourage students to improve their \\
vocabulary mastery (mufrodat). However, learning Flash- \\
card so far is still considered boring. This study aims to re- \\
veal the extent to which Flashcards are produced and used \\
in the process of learning foreign languages in Indonesia \\
(English and Arabic). The method used in this research is \\
the study of literature by collecting a number of documents \\
in the last 10 years of research on English and Arabic \\
Flashcard research. In addition to articles, literature in the \\
form of books and multilingual Flashcards also contributed \\
to research data as well as being used as a validation tool by \\
using data source triangulation techniques. The results of \\
this study reveal the production of Arabic Flashcards have
\end{tabular}
\end{abstract}


not used as many themes as English Flashcards. In addition, the use of Flashcards in a variety of learning methods can make students feel challenging learning. Therefore, further research is recommended to develop Flashcard products based on themes.

\section{PENDAHULUAN}

Flashcard merupakan alat bantu proses pembelajaran (Hotimah, 2010; Laeli, 2010). Proses pembelajaran tersebut senantiasa ditujukan untuk peningkatan penguasaan kosakata peserta didik. Peserta didik yang memiliki tingkat penguasaan atas kosakata yang baik dapat mendukung keterampilan berbahasa.

Peserta didik Indonesia yang didominasi oleh penganut agama Islam memiliki kecenderungan memelajari sekurang-kurangnya dua bahasa Asing, yakni bahasa Inggris dan bahasa Arab. Bahasa Inggris diyakini oleh para peserta didik sebagai jembatan dalam memeroleh wawasan keilmuan yang bersifat global atau internasional. Sementara bahasa Arab diyakini oleh para peserta didik dalam menguasai bidang keilmuan agama.

Salah satu upaya yang dapat dilakukan untuk menguasai kedua bahasa Asing tersebut yakni dengan meningkatkan jumlah perbendaharaan kata. Bahkan sejumlah sekolah juga menye- lenggarakan proses pembelajaran dengan memberikan bahasa Inggris dan bahasa Arab sebagai muatan kurikulum pembelajaran.

Tak hanya sekolah, sejumlah produsen juga turut memroduksi alat bantu pembelajaran dengan multi bahasa (bahasa Arab, Inggris dan Indonesia) sebagaimana tampak pada gambar 1 .

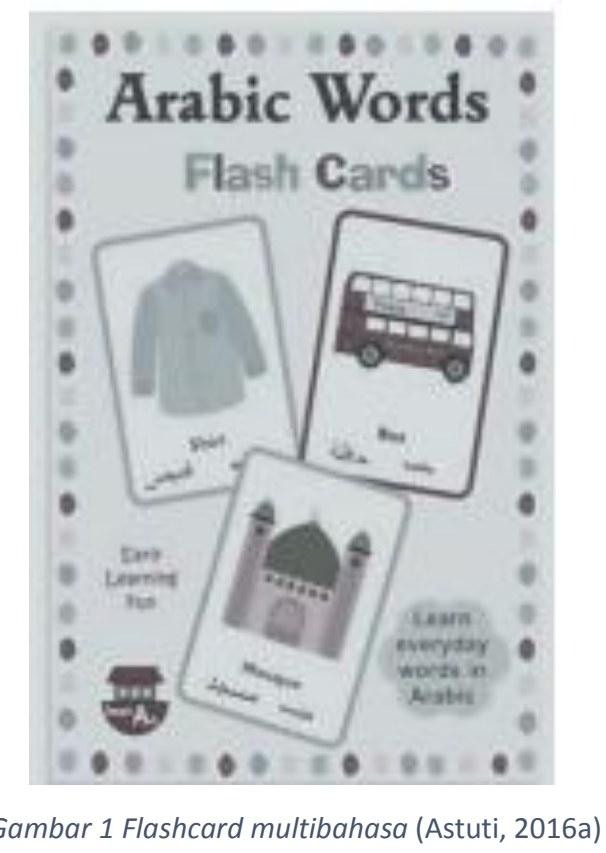

Selain itu sejumlah penelitian pengembangan Flashcard telah dilakukan dengan hasil produk pengembangan didominasi dengan unsur gambar dan tulisan (Iswari, 2017; Safitri, 2020).

Tak hanya Flashcard berbentuk fisik, telah hadir pula Flashcard berbentuk di- 
gital (Rifqiawan, 2016). Flashcard fisik maupun digital mempunyai peranan yang serupa yakni tetap berfoku pada upaya peningkatan penguasaan kosakata peserta didik

Eksistensi Flashcard sebagai media atau alat bantu pembelajaran tentunya memerlukan perhatian khusus para pendidik sedari pembuatan hingga implementasi Flashcard di dalam kelas.

Tak heran apabila sejumlah penelitian mencoba mengungkap besaran pengaruh penggunaan media Flashcard dalam proses pembelajaran baik tingkat taman kanak-kanak ((Kusumawati \& Mariono, 2016) dan tingkat sekolah dasar (Hotimah, 2010; Laeli, 2010; Muzakki et al., 2012; Safitri, 2020; Umroh, 2019).

Penelitian ini hampir memiliki kemiripan dengan penelitian Astuti (2016b). Penelitian tersebut mengungkap penggunaan gambar pada Flashcard dalam proses pembelajaran bahasa Arab. Adapun penelitian pada artikel ini bertujuan mengungkap bagaimana Flashcard diproduksi dan digunakan dalam proses pembelajaran bahasa asing di Indonesia yakni bahasa Inggris dan bahasa Arab. Dalam rangka mengungkap tujuan penelitian tersebut, penelitian ini merumuskan dari sejumlah pertanyaan penelitian antara lain 1) bagaimana Flashcard bagi para pendidik di era revolusi industry 4.0 , 2) bagaimana peranan Flashcard bagi peserta didik, 3) bagaimana implementtasi Flashcard dalam pembelajaran bahasa, dan 4) ragam kebahasaan pada Flashcard dengan memerhatikan kesesuaian usia yang harus dikuasai peserta didik

\section{METODE}

Penelitian ini dilaksanakan dengan menggunakan metode studi literatur (Auerbach \& Silverstein, 2003; Kothari, 2004; Sherman \& Webb, 2005; Stake, 2010). Data diperoleh dengan mengumpulkan sejumlah jurnal dalam 10 tahun terakhir (2010-2020) terkait dengan Flashcard di Indonesia. Informasi yang berkenaan dengan kesejarahan, pemanfaatan serta implementasi Flashcard dikelompokkan untuk menggeneralisasikan hasil temuan. Selain itu pengumpulan sejumlah pustaka baik buku maupun dokumen fisik Flashcard yang diperjualbelikan di toko daring juga dilakukan untuk menambah data temuan. Guna menguji keabsahan temuan data penelitian, teknik triangulasi sumber data dipergunakan. Teknik triangulasi sumber 
ini dilakukan dengan cara mencocokkan data temuan penelitian dengan sumber buku mengenai Flashcard, dokumen fisik Flashcards, dan jurnal lain yang sejalan dengan substansi temuan.

HASIL \& PEMBAHASAN Flashcard bagi Pendidik Industri 4.0

Pendidik di era revolusi industry 4.0 semaksimal mungkin memanfaatkan segala ragam media pembelajaran untuk mengomunikasikan sejumlah materi. Bentuk pengomunikasian materi ke siswa secara baik dinilai mampu memberikan suasana belajar yang menyenangkan bagi peserta didik. Sebagai contoh, penyampaian pembelajaran menggunakan video di awal pembelajaran dapat menarik atensi siswa untuk tertarik memelajari sebuah materi (Sueca, 2013; Yunita \& Wijayanti, 2017).

Video dipahami sebagai kumpulan gambar yang bergerak. Peserta didik yang kurang cepat dalam proses pemahaman proses pembelajaran dengan gambar yang bergerak tentunya membutuhkan alternatif proses pembelajaran. Salah satunya adalah dengan memberikan gambar yang bersifat statis.

Gambar statis ini dapat membantu pendidik dalam melakukan pengelolaan waktu pembelajaran menjadi lebih terorganisir dan tepat sasaran. Dengan kata lain, penggunaan gambar statis cukup mengulang atau memberikan durasi yang lebih lama pada gambar yang dianggap belum dipahami peserta didik. Gambar statis tersebut dikenal dengan istilah Flashcard.

Flashcard merupakan sekumpulan kartu yang bersifat informatif memuat gambar atau kata pada satu atau kedua sisi (Arsyad, 2006) dan dapat dijadikan permainan (Kusumawati \& Mariono, 2016). Bentuk Flashcard yang praktis juga menjadi salah satu pertimbangan para pendidik menggunakan media pembelajaran ini. Praktis yang dimaksudkan adalah Flashcard dapat dibawa karena ukuran yang handy (mudah digenggam) hingga dapat disimpan di dalam tas, saku, dan tidak membutuhkan tenaga listrik.

Baik video maupun Flashcard, peserta didik sejatinya lebih menyukai pembelajaran yang bersifat visual dan berwarna. Adapun pembelajaran bahasa asing di Indonesia, baik bahasa Inggris maupun bahasa Arab, cenderung mengutamakan peningkatan kosakata. Oleh karena itu, Flashcard yang dapat dipergunakan pendidik diupayakan 
menyesuaikan kebutuhan kosakata peserta didik.

Secara ringkas, pendidik dapat memergunakan Flashcard dengan sejumlah faktor sebagai berikut: 1) peserta didik kurang cepat memahami pembelajaran yang bersifat realia, 2) peserta didik membutuhkan pemahaman lebih secara rinci atas tiap penambahan kosakata yang ditargetkan pendidik, dan 3) peserta didik cenderung membutuhkan perhatian ekstra pendidik saat proses pembelajaran.

\section{Peranan Flashcard}

Sejumlah faktor pendorong dalam menggunakan Flashcard yang telah disebutkan sebelumnya, media pembelajaran ini memiliki kedudukan tersendiri dalam proses pembelajaran. Proses pembelajaran secara tidak langsung diarahkan kepada pembelajaran yang berpusat pada peserta didik. Ukuran Flashcard yang kecil memaksa pengaturan pembelajaran menjadi bersifat individu, berpasangan, atau berkelompok dalam jumlah kecil (3-4 orang).

Selain jumlah orang yang melakukan proses pembelajaran, perhatian peserta didik menjadi lebih terfokus pada gambar atau kata yang sederhana. Sebagai contoh, huruf / alif/ pada gam- bar 2 merupakan aksara bahasa Arab berbentuk garis lurus vertikal. Pada Flashcard tersebut juga disediakan informasi tambahan, antara lain: 1) transliterasi bahasa Arab ke dalam bahasa Indonesia, dan 2) penggunaan fathah, kasrah, dan dhammah.

Sajian pada tiap Flashcard memicu peserta didik untuk mengingat dalam waktu yang cepat. Adanya kemiripan bentuk dan secara bertahap ditambahkan sejumlah variasi seperti gambar 2 akan membuat suasana proses pembelajaran menjadi lebih menantang. Melalui Flashcard tersebut, peserta didik dituntut memahami konsep yang disajikan secara akurat.

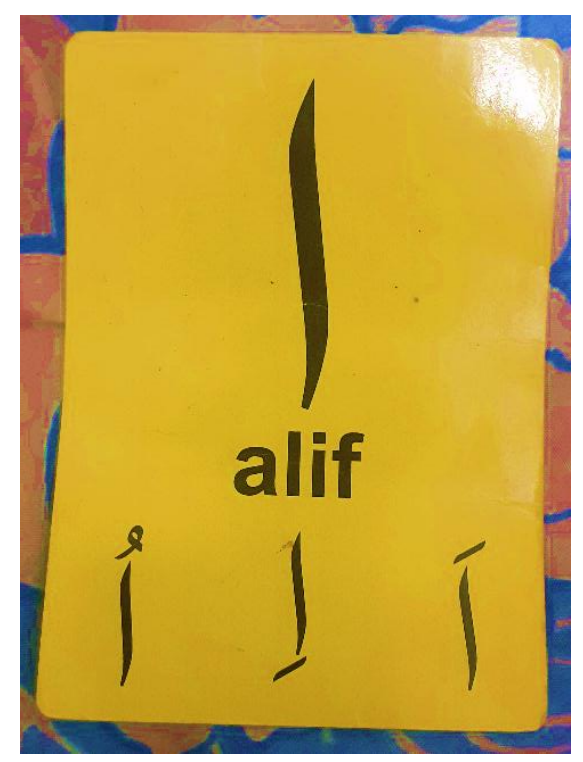

Gambar 2 Flashcard Huruf Hijaiyah-Alif

Penggunaan Flashcard sebagai awalan pembelajaran dijadikan sebagai bukti fisik individu dalam melakukan hafal- 
Flashcard: Belajar Mufrodat Bahasa Arab Semakin Menantang

an. Misalnya saja seorang anak yang sedang melakukan hafalan huruf hijaiyah dan cara pengucapan huruf tersebut. Peserta didik datang kepada pendidiknya untuk melaporkan hasil hafalan. Peserta didik meletakan kartu sesuai gambar 2 lalu mengujarkan "alif, alif fathah - a, alifkasrah - $i$, alif dhammah - $u^{\prime \prime}$. begitu seterusnya hingga huruf terakhir yakni huruf /ya/.

Pada tahap lanjut, peserta didik yang telah mampu membaca ditambahkan tingkat kesulitan berbahasanya seperti gambar 3 di bawah ini.

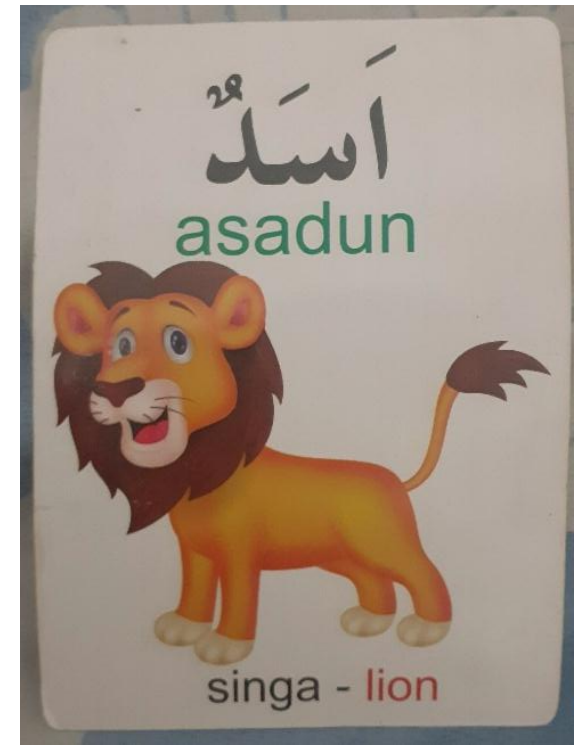

Gambar 3 Flashcard Gambar dan Kata

Peserta didik dapat menggunakan Flashcard sesuai gambar 3 apabila telah mampu membaca kata. Proses pembelajaran pada tahapan ini jauh lebih kompleks dibandingkan sebelumnya. Peserta didik diharapkan mampu membaca bahasa Arab, transliterasi bahasa Arab, bahasa Inggris, dan bahasa Indonesia. Kata pada Flashcard memang beragam bahasa namun keberadaan gambar dapat memudahkan seseorang untuk memahami kosakata asing.

\section{Flashcard dalam Pembelajaran Bahasa}

Pembelajaran bahasa yang menggunakan Flashcard senantiasa bertujuan untuk peningkatan kosakata. Flashcard untuk pembelajaran bahasa Inggris kini berkembang menjadi seri Flashcard berdasarkan tema tertentu. Misalnya tema angka, huruf, buah, hewan, pekerjaan, hobi dan sebagainya.

Berbeda dengan Flashcard Bahasa Inggris, Flashcard bahasa Arab masih banyak mengusung tema huruf dan angka. Adapun Flashcard bahasa Arab mengaitkan huruf dengan hewan atau benda yang berkaitan dengan awalan huruf hijaiyah. Misalnya huruf alif dikorelasikan dengan /asadun/ seperti pada gambar 3 .

Korelasi huruf alif dan kata asadun yakni terjadi pengulangan pada huruf awalan. Pengulangan yang berfokus pada satu huruf awalan ini sejalan dengan metode spaced-repetition (Raaijmakers, 2003). Kemampuan memori otak manusia dalam mengasosiasikan informasi 
yang berulang menjadikan memori tersebut dapat tersimpan lebih lama pada otak. Metode ini memanfaatkan jarak atau jeda yang dialami otak. Saat belajar, otak manusia sanggup menguasai pada titik optimal hafal tertentu. Seiring dengan berjalannya waktu, memori tersebut akan menurun. Namun, orang tersebut tidak memerlukan pengulangan pembelajaran dari awal hingga kembali pada titik optimal hafalnya (Kornell, 2009).

Flashcard seperti ini membantu proses pembelajaran pengenalan huruf melalui penautan pemakaian huruf hijaiyah yang diselaraskan dengan pemahaman kultural peserta didik. Selain itu, pemilihan gambar juga masih berupa kartun atau gambar animasi sehingga tampak lebih menarik di mata peserta didik usia anak-anak. Contoh lainnya juga tampak pada gambar 4 .

Sejumlah pengembangan Flashcard bahasa Arab dalam pembelajaran di kelas telah banyak dilakukan, yakni tema keluarga (Safitri, 2020) dan tema binatang (Kusumawati \& Mariono, 2016).

Tak hanya pengembangan di bidang tema, ukuran Flashcard pun turut juga dikembangkan. Flashcard yang banyak diperjualbelikan di toko buku maupun toko daring berukuran $10 \mathrm{x}$ $12 \mathrm{~cm}$ berbahan art paper dengan dilapisi glossy.

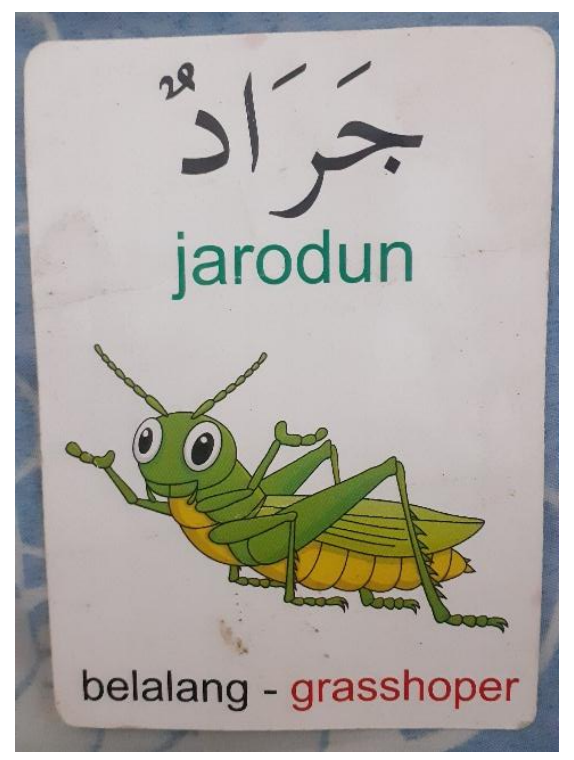

Gambar 4 Pemilihan Gambar Berdasarkan Huruf Awalan

Ukuran tersebut efektif apabila dilaksanakan pada kelompok kecil (1-4 orang). Sementara pendidik di Indonesia berkewajiban melayani 20-36 orang dalam satu kelas. Salah satu alternatif solusi yang bias ditawarkan adalah mengubah ukuran Flashcard menjadi lebih besar 15 x $14 \mathrm{~cm}$ (Safitri, 2020) hingga ukuran A4 (Gelfgren, 2012).

Demi menjaga kesinambungan pembelajaran menggunakan Flashcard, pendidik disarankan untuk melaminasi menggunakan plastik. Kegunaan laminasi tiap Flashcard akan memertahankan warna gambar dan kartu tidak mudah rusak. 
Flashcard: Belajar Mufrodat Bahasa Arab Semakin Menantang

Mengingat biaya produksi Flashcard yang terbilang cukup mahal. Sebagian pendidik turut membuat versi digital dengan bantuan program presentasi seperti aplikasi Microsoft Powerpoint.

Pembelajaran dengan program presentasi akan membutuhkan sejumlah alat yakni laptop dan proyektor. Tampilan digital tentunya dapat disesuaikan dengan jumlah besaran peserta didik di dalam kelas.

Perlu diketahui, apapun besaran dan jenis alat yang digunakan (Flashcard digital atau nondigital) sebaiknya memenuhi kaidah pembelajaran kosakata.

Ragam Pembelajaran Kosakata pada

\section{Flashcard}

Kosakata (mufrodat) merupakan ukuran kapasitas peserta didik dalam memahami persoalan dalam kehidupan sehari-hari. Semakin banyak mufrodat yang dikuasai, maka semakin mudah menguasai keterampilan berbahasa (berbicara, mendengarkan, menulis, dan membaca).

Namun kuantitas kosakata tidak sepenuhnya menjadi ukuran kecakapan seseorang telah menguasai bahasa. Kecakapan tersebut diukur seberapa sering menggunakan padanan kata yang tepat dan komunikatif. Sehingga pem- belajaran tak sekedar hanya menambah ukuran kuantitas mufrodat, melainkan juga harus menyesuaikan level usia pengguna saat belajar menggunakan Flashcard.

Adapun proses pembelajaran yang menggunakan Flashcard dapat berupa: 1) kamus/lexicon/maejam, 2) alphabet/ alphabet/abjad, 3) ujaran/pronunciation/ nataq, 4) tata kalimat/grammar/qawaid, 5) kuis/quiz/aikhtibar, 6) bermain peran/ role play/laeib'adwar, 7) sinonim/synonym/muradif, 8) antonym/antonym/alkalimat almudada, 9) angka/numbers/"aedad (lihat gambar 5), dan 10) matematika/ math/alriyadiat.

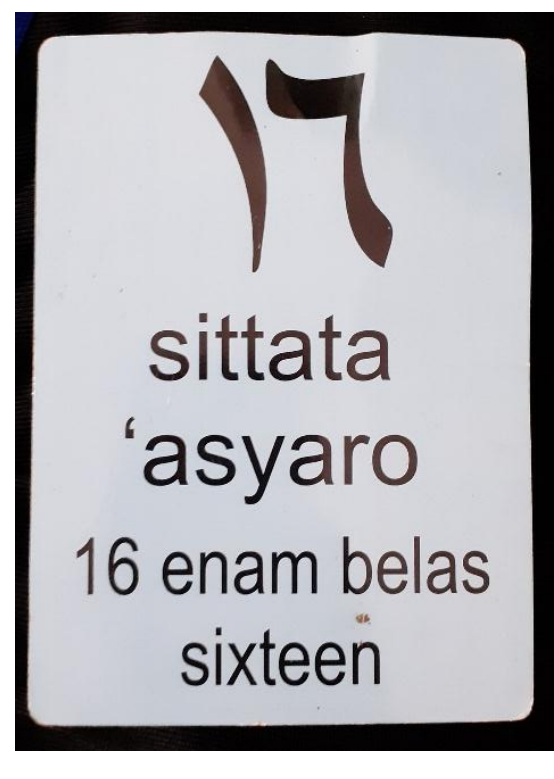

Gambar 5 Flashcard 'aedad

Flashcard pun harus mengikuti perkembangan usia anak. Usia anak membedakan pemerolehan bahasa sehingga 
pendidik harus menyesuaikan Flashcard yang dibuat berdasarkan kosakata yang berkenaan dengan tingkatan usia.

Misalnya Flashcard yang diproduksi dengan berbasis lagu nama-nama bulan hijriyah yang dipopulerkan oleh karakter animasi Nussa dan Rara (Adista, 2019). Melalui lagu dibuat sebanyak 12 kartu yang berisikan penulisan dan pengucapan nama-nama bulan hijriah. Kartu-kartu tersebut dipergunakan selama lagu diputar. Setiap nama bulan disebutkan, peserta didik diminta mengangkat kartu yang bertuliskan nama bulan tersebut. Pembelajaran Flashcard ini cocok diterapkan untuk usia anakanak maupun peserta didik dengan kategori pemula.

Sementara untuk usia lebih dewasa atau peserta didik dengan kategori madya atau tingkat lanjut dapat memergunakan Flashcard dengan ragam gambar dan kata dengan tema hewan, tumbuhan, transportasi dan sebagainya. Pendidik dapat membuat ragam permainan dengan menggunakan Flashcard ini. Salah satunya dengan siapkan sejumlah Flashcard pada satu bejana atau wadah. Pendidik memberikan rangsangan berupa pertanyaan misalnya saja 'man anaa? Aha'bu an usiha fi sa'bahi".
Peserta didik yang mengetahui jawabannya segera menuju bejana dan mencari jawaban (diikun) pada kartu untuk kemudian ditunjukkan kepada teman lainnya.

Peserta didik dengan tahapan lanjut dapat menggunakan Flashcard kepada teman sejawat dengan bantuan perintah atau pertanyaan dari Flashcard. Misalnya peserta didik A membacakan "tahadatsa'an syakhshin laa tuhibbuhu", kemudian peserta didik B menjawab dengan batasan waktu yang telah disepakati. Begitu pula sebaliknya secara bergantian.

\section{SIMPULAN}

Berdasarkan paparan yang dikemukakan sebelumnya, Flashcard memiliki ketentuan sebelum dan sesudah proses pembelajaran bahasa asing. Pada dasarnya ketercapaian pembelajaran bahasa merupakan gerbang kepada tingkatan yang lebih tinggi.

Beberapa poin penting dalam penelitian ini dapat diutarakan sebagai berikut bahwa Flashcard diproduksi didasarkan atas kebutuhan peserta didik dan target pembelajaran yang ingin dicapai. Pemilihan bahan dan materi serta tema disesuaikan agar dapat mengakomodasi ragam kebutuhan peserta didik dan 
dapat dipergunakan secara berkesinambungan oleh para pendidik.

Flashcard dapat dikemas menjadi proses pembelajaran yang menantang. Setiap peserta didik dilibatkan dalam sebuah permainan yang menuntut konsentrasi untuk menuntaskan ragam permainan atau ragam metode yang disajikan para pendidik, yakni dapat berupa lagu, tebak gambar, maupun bermain peran.

Dibanding bahasa Inggris, bahasa Arab sulit dijumpai ragam Flashcard dengan penyesuaian tema. Oleh karena itu, penelitian pengembangan Flashcard berdasarkan tema masih sangat perlu dilakukan.

\section{DAFTAR PUSTAKA}

Adista, D. (2019). Lirik Bulan Hijriah Penuh Berkah. Musixmatch. https://www.musixmatch.com/ly rics/Nussa/Bulan-Hijriah-PenuhBerkah

Arsyad, A. (2006). Media Pembelajaran. PT. Raja Grafindo Persada.

Astuti, W. (2016a). BERBAGAI STRATEGI PEMBELAJARAN KOSA KATA BAHASA ARAB. Jurnal Komunikasi Dan Pendidikan Islam, 5(2), 177-191.

Astuti, W. (2016b). MEDIA FLASHCARDS SEBAGAI MEDIA PEMBELAJARAN BAHASA ARAB YANG EFEKTIFUNTUK MENINGKATKAN PERBENDAHARAAN KOSAKATA SISWA. Journal AlManar, 5(1).
Auerbach, C. F., \& Silverstein, L. B. (2003). Qualitative Data. New York University Press.

Gelfgren, V. (2012). Fun With Flashcard. LEARNMORE PROJECTS.

Hotimah, E. (2010). Penggunaan Media Flashcard Dalam Meningkatkan Kemampuan Siswa Pada Pembelajaran Kosakata Bahasa Inggris Kelas II MI Ar-Rochman Samarang Garut. Jurnal Pendidikan Universitas Garut, 04(01), 10-18. https://journal.uniga.ac.id/index. $\mathrm{php} / \mathrm{JP} /$ article/download/30/30

Iswari, F. (2017). Pengembangan Media Pembelajaran Bahasa Inggris Berupa Flashcard Bergambar pada Tingkat Sekolah Dasar. Deiksis, 9(02), 119.

https://doi.org/10.30998/deiksis. v9i02.1375

Kornell, N. (2009). Optimising Learning Using Flashcards: Spacing Is More Effective Than Cramming. Applied Cognitive Psychology, 23, 1297-1317. https://doi.org/10.1002/acp

Kothari, C. R. (2004). Research Methodology: Methods and Techniques. New Age International.

Kusumawati, R., \& Mariono, A. (2016). Pengembangan Media Flashcard Tema Binatang untuk Anak Kelompok B di Taman Kanakkanak Asemjajar-Surabaya. Teknologi Pendidikan, 4(1), 24-32.

Laeli, A. F. (2010). USING FLASHCARD AS A MEDIA IN TEACHING VOCABULARY TO YOUNG LANGUAGE LEARNERS. Didaktika, 6(1), 35-43.

Muzakki, M. S., Widodo, A. T., \& Raharjo, T. J. (2012). Keefektifan Pembelajaran Bahasa Inggris Berbantuan Media Flashcards Untuk Meningkatkan Hasil Belajar Siswa. Innovative Journal of 
Curriculum and Educational

Technology, 1(2), 82-86.

Raaijmakers, J. G. W. (2003). Spacing and repetition effects in human memory: Application of the SAM model. Cognitive Science, 27(3), 431452.

https://doi.org/10.1016/S03640213(03)00007-7

Rifqiawan, R. A. (2016). PEMBUATAN

FLASH CARD DIGITAL UNTUK

PEMBELAJARAN 80\% KOSA

KATA AL-QUR'AN Raden. Jurnal

At-Taqaddum, 8(1), 1-20.

https://doi.org/10.1017/CBO9781

107415324.004

Safitri, K. (2020). PENGEMBANGAN

KARTU KATA (FLASH CARD)

BAHASA ARAB BERBASIS

KOSAKATA BAGI SISWA KELAS

IV MADRASAH IBTIDA ' IYAH.

Prosiding Seminar Nasional Bahasa

Arab Mahasiswa IV, 272-283.

Sherman, R. R., \& Webb, R. B. (2005).

Qualitative Research in Education:

Focus and Methods. Taylor \&

Francis.

Stake, R. E. (2010). Qualitative Research: studying how things work. The Guildford Press.

Sueca, I. N. (2013). Penggunaan Video Pantomim untuk Meningkatkan

Keterampilan Menulis Naskah Drama di Kelas VIII B SMP Negeri

3 Rendang. Journal of Chemical Information and Modeling, 1(1), 1689-1699.

https://doi.org/10.23887/ijpbs.v1i $\underline{1.274}$

Umroh, I. L. (2019). PENGARUH

PENGGUNAAN MEDIA FLASH

CARD TERHADAP

PEMBELAJARAN KOSA KATA

BAHASA ARAB (STUDY

EKSPERIMEN TERHADAP

SISWA KELAS 1 SD NEGERI

TLOGOREJO SUKODADI

LAMONGAN). DAR EL-ILMI:

Jurnal Studi Keagamaan, Pendidikan

Dan Humaniora, 6(1), 39-58.

Yunita, D., \& Wijayanti, A. (2017).

Pengaruh Media Video

Pembelajaran Terhadap Hasil

Belajar IPA Ditinjau Dari Keaktifan

Siswa. Sosiohumaniora: Jurnal Ilmiah

Ilmu Sosial Dan Humaniora, 3(2). 